\title{
PENGELOLAAN SAMPAH RUMAH TANGGA (STUDI PENELITIAN DI DESA KARANG INTAN KECAMATAN KARANG INTAN KABUPATEN BANJAR)
}

\author{
Jumarianta \\ FIA, Universitas Achmad Yani Banjarmasin \\ Email: masjummae@gmail.com
}

\begin{abstract}
This research intends to find, understand and explain the problems as the phenomenon that occurs. Data collecting researchers do by using more and collect information by deepening the phenomenon studied. Then make an analysis by connecting the existing facts and the data that the researchers get in the field in accordance with the results of observation. After the data obtained from the field then the data is processed and analyzed by qualitative descriptive way that describes and explains precisely in accordance with the actual situation about the problems in the carefully derived from data that has been collected so that can be drawn conclusions appropriately. The results showed that $64 \%$ of the respondents acknowledged the existence of a very important role of local community leaders, while 36\% of the community expressed no role from either government in terms of providing socialization / training on how to manage good waste. While 58\% of the respondents stated that the infrastructure facilities for waste management of Village Karang Intan are still lacking, while the remaining $32 \%$ assumed that the infrastructure was enough because the respondent community was in front of the road contained in the trash bin, $10 \%$ of the respondents did not there is an answer. Public participation in waste management directly $54 \%$ of respondents did not carry out activities directly to manage the environment, and $16 \%$ rarely did, and $7 \%$ of respondents were quite frequent and $16 \%$ frequently carried out waste management activities.
\end{abstract}

Keywords: management, garbage, household

\section{PENDAHULUAN}

Masalah sampah di Indonesia merupakan masalah yang rumit karena kurangnya pengertian masyarakat terhadap akibat-akibat yang dapat ditimbulkan oleh sampah, kurangnya biaya pemerintah untuk mengusahakan pembuangan sampah yang baik dan memenuhi syarat, begitu pula halnya yang terjadi di desa Karang Intan dalam pengelolaan sampah rumah tangganya.

Sampah merupakan hal yang sangat berpengaruh dan berdampak negatif bagi kesehatan dan kelangsungan hidup masyarakat. Sampah dapat membawa dampak yang buruk pada kondisi kesehatan manusia. Bila sampah dibuang secara sembarangan atau ditumpuk tanpa ada pengelolaan yang baik, maka akan menimbulkan berbagai dampak kesehatan yang serius.
Kadang-kadang manusia tidak menyadari bahwa setiap hari manusia dalam keluarga pasti menghasilkan sampah, baik sampah organik maupun sampah anorganik. Sehingga perlunya suatu pengelolaan sampah yang berkelanjutan dan baik agar sampah bisa dikendalikan.

Sebagian dari mereka yang masih peduli dengan lingkungannya mencoba membakar sampah-sampahnya di halaman rumah. Namun ada juga masyarakat yang tidak punya banyak waktu untuk melakukannya dan memilih cara praktis yaitu membuangnya ke sungai atau selokan. Dampaknya adalah ketika musim hujan tiba, sampah-sampah tersebut menghambat laju air di saluran-saluran air yang menyebabkan air tidak bisa mengalir. Karena mengendap cukup lama, air tersebut mulai menjadi tempat dimana ancaman-ancaman penyakit mulai menyerang. 
Partisipasi seluruh warga masyarakat khususnya dalam penelitian ini adalah masyarakat Desa Karang Intan mutlak diperlukan untuk mewujudkan lingkungan yang bersih sehingga semua warga yang tinggal di wilayah tersaebut bisa menikmati kehidupan dengan sehat dan nyaman. Saat ini masih banyak kita temui orang-orang yang mementingkan diri sendiri atau mengabaikan lingkungan, sehingga tidak bertanggungjawab untuk turut berpartisipasi membersihkan lingkungan dengan berbagai macam alasan seperti sibuk bekerja, tidak punya waktu luang, sering keluar daerah, dan lain-lain. Sesungguhnya kita perlu menganggap serius masalah tersebut. Kita perlu memikirkan jalan keluar yang paling baik karena jika masalah ini dibiarkan, masyarakat yang lain akan merasakan adanya diskriminasi yang akan menyebabkan mereka juga ikut-ikutan tidak mau berpartisipasi dalam kegiatan-kegiatan yang pengelolaan sampah rumah tangga tersebut.

Ada beberapa cara yang bisa dilakukan oleh pemerintah dalam pengelolaan sampah rumah tangga, seperti memberikan apresiasi kepada orang (masyarakat) yang sadar untuk mengelola sampah rumah tangganya, dengan cara memilah dan membuang pada tempat yang sudah disediakan. Cara-cara seperti ini diharapkan akan menumbuhkan budaya masyarakat akan pentingnya lingkungan yang bersih dan sehat melalui pengelolaan sampah yang ada di rumah tangganya masing-masing. Dengan demikian setiap warga masyarakat dihimbau untuk turut peduli terhadap lingkungan supaya lingkungan tetap bersih dan sehat karena masalah sampah mutlak harus ditangani secara terhitung sejak bulan Mei 2017 sampai dengan bulan Juli 2017.

Untuk memperoleh data peneliti mengumpulkan data dengan cara menyebarkan angket yang sudah disiapkan kepada warga masyarakat RT.1, RT.2 dan RT.3 yang dijadikan sebagai responden dalam penelitian sebanyak 85 orang, serta dilakukan wawancara. Setelah data diperoleh dari lapangan selanjutnya data diolah dan dianalisa dengan cara deskriptif kualitatif yaitu menggambarkan dan menjelaskan secara tepat sesuai dengan keadaan yang sebenarnya tentang permasalahan bersama-sama antara pemerintah, lembaga swadaya masyarakat dan masyarakat itu sendiri. Oleh sebab itu, dibutuhkan kesadaran dan komitmen bersama menuju perubahan sikap, prilaku, etika yang berbudaya lingkungan. Pengelolaan sampah yang dapat dilakukan masyarakat untuk mengurangi jumlah sampah yang masuk ke TPA diantaranya pengkomposan karena dapat menjadikan pupuk yang dapat menyuburkan tanaman.

Dari uraian diatas nampak bahwa tingkat partisipasi masyarakat dalam pengelolaan sampah rumah tangga di Desa Karang Intan masih rendah. Oleh karena itu fokus penelitian diarahkan pada bagaimana agaimana partisipasi masyarakat lokal dalam hal ini masyarakat Desa Karang Intan Kabupaten Banjar dalam mengelola sampah rumah tangga, dilihat dari beberapa aspek dasar mengenai karakteristik masyarakat yang dijadikan sebagai reponden penelitian, pengetahuan dan pengalaman masyarakat mengenai pengelolaan sampah rumah tangga, peran pemerintah/tokoh masyarakat, sarana dan prasarana yang tersedia dalam kegiatan pengelolaan sampah rumah tangga, persepsi dan partisipasi masyarakat terhadap pengelolaan sampah rumah tangga.

\section{METODE PENELITIAN}

Penelitian ini dilakukan di wilayah Desa Karang Intan Kecamatan Karang Intan Kabupaten Banjar, khususnya di wilayah RT. 1, RT. 2 dan RT. 3. Sedangakn waktu penelitian dilakukan selama 3 (tiga) bulan.

yang di teliti yang berasal dari data yang telah dikumpulkan sehingga dapat diambil kesimpulan secara tepat.

\section{HASIL DAN PEMBAHASAN}

\section{Tindakan masyarakat dalam mengelola sampah}

Dari aspek tentang tindakan masyarakat dalam pengelolaan sampah rumah tangga, dapat diketahui sebagaimana tabel berikut : 
Tabel 1. Tindakan Masyarakat Dalam Mengelola Sampah Rumah Tangga

\begin{tabular}{clcr}
\hline No. & \multicolumn{1}{c}{ Klasifikasi Pelapor } & Frekuensi & $\%$ \\
\hline 1. & Dibuang ke selokan & 5 & 6 \\
2. & Dibakar & 57 & 67 \\
3. & Didaur ulang & 22 & 26 \\
4. & Disembunyikan & 1 & 1 \\
& & & \\
\hline & Jumlah & 85 & 100,0 \\
\hline
\end{tabular}

Sumber : Data Primer 2017

Dari tabel diatas dapat diketahui bahwa tindakan masyarakat dalam mengelola sampah rumah tangga yang sudah terkumpul, menunjukkan bahwa masyarakat lebih memilih untuk membuang keselokan sebanyak $6 \%$. Alasannya bahwa membuang sampah ke selokan terasa lebih praktis tanpa harus repot mengumpulkan.

Sebagian besar masyarakat responden yaitu sebanyak $67 \%$ mengatakan bahwa untuk mengelola sampah rumah tangga yang sudah terkumpul kemudian dibakar. Menurut mereka dilakukan pembakaran terutama pada sampah kering dengan maksud agar tidak menumpuk.

Sedangkan masyarakat yang mengelolasampah dengan melakukan daur ulang terhadap sampah yang terkumpul ada sebanyak
$26 \%$. Bentuk daur ulang disini adalah dengan menimbun untuk dijadikan pupuk. Hal ini menunjukkan bahwa sebenarnya sebagian besar responden telah mengetahui yang apa yang harus dilakukan terhadap sampah yang terkumpul, agar sampah tidak menjadi masalah yang besar baik dimasa sekarang ataupun masa yang akan datang.

\section{Pengalaman Masyarakat Dalam Mengelola Sampah}

Dari aspek pengalaman masyarakat dalam menglola sampah rumah tangga, responden mengakui bahwa masyarakat sebenarnya sudah terbiasa mengelola sampah. Kegiatan pengelolaan sampah rumah tangga yang biasa dilakukan masyarakat di Desa Karang Intan dapat dirinci dalam tabel berikut :

Tabel 2. Pengalaman Masyarakat Dalam Mengelola Sampah

\begin{tabular}{clcr}
\hline No. & \multicolumn{1}{c}{ Klasifikasi Pelapor } & Frekuensi & \% \\
\hline 1. & Mengelola sampah menjadi kompos & 13 & 15 \\
2. & Membuat kerajinan dari barang bekas & 14 & 16 \\
3. & Memilah sampah organik dan anorganik & 13 & 15 \\
4. & Menabung sampah di bank sampah & 11 & 13 \\
5. & Memindahkan sampah ke TPS & 15 & 18 \\
6. & Kerja bakti membersihkan lingkungan & 10 & 12 \\
7. & Mengikuti kegiatan pelatihan & 2 & 2 \\
8. & Mengikuti sosialisasi/penyuluhan & 7 & 8 \\
& & & 100,0 \\
\hline
\end{tabular}

Sumber : Data Primer 2017

Dari aspek pengalaman pengelolaan sampah rumah tangga pada masyarakat Desa Karang Intan berdasarkan data wawancara diproleh 8 kegiatan yang berkenaan dengan pengelolaan sampah yaitu :

a. Mengolah sampah menjadi kompos pada kegiatan ini ada 13 orang jumlahnya yang mengakui pernah melakukan kegiatan tersebut, hal ini menyatakan bahwa kegiatan ini kurang diminati oleh masyarakat dikarenakan pembuatan kompos yang memerlukan waktu dan usaha ketimbang mengakui pupuk pabrik.

b. Membuat kerajinan dari barang bekas pada peluang ini terdapat 14 orang yang 
mempunyai pengalaman melakukan, hal ini menunjukkan bahwa hanya sedikit masyarakat yang mempunyai inisiatip untuk mempaatkan barang-barang sisa yang menjadi sampah untuk diolah menjadi barang yang berguna bagi dan bahkan bernilai ekonomis.

c. Memisahkan sampah organik dan anorganik pada kegiatan ini terdapat 13 orang yang melakukan, kemudian hal ini menunjukkan bahwa kegiatan pemisahan sampah tersebut. Menjadi hal yang dianggap kurang perlu dilakukan, dikarenakan asumsi masyarakat yang menyatakan petugas sampahlah atau beda pengelola sampah yang bertugas untuk memilah sampah.

d. Menabung dibank sampah hanya 11 orang dari selain responden yang mengalami pernah melakukan kegiatan ini dikarenakan bahwa lembaga atau badan pengelola sampah tersebut tidak ada di desa karang intan yang ada hanya TPA.

e. Memidahkan samph ke TPS pada kegiatan ini lebih dari setengah responden yaitu 15 orang melakukannya. Hal ini menunjukkan bahwa kegiatan ini menjadi usaha rutin yang dilakukan warga dalam bentuk mengatasi tentang sampah yang termasuk dalam pengelolaan sampah agar tidakterjadi penumpukan sampah baik itu dirumah tangga maupun dilingkungan sekitar.

f. Kerja bakti membersihkan lingkungan dari hasil yang diproleh dari tanggapan responden, 10 orang mengatakan pernah melakukan kegiatan ini dan hal ini menunjukkan bahwa mayoritas warga mempunyai partisipasi yang baik dalam menjaga atau mengelola lingkungannya agar tetap asri terhindar dari sampah yang mengotori lingkungan.

g. Mengikuti kegiatan atau pelatihan yang diselenggarakan oleh lembaga yang mengelola sampah rumah tangga. pada kegiatan ini hanya 2 orang dari banyak responden yang dipilih yang mengakui pernah melakukan atau mengikuti dan ini menjukkan bahwa, lembaga atau badan pengelola sampah didesa setempat tidak pernah melakukan penelitian pengelolaan sampah secara terbuka terhadap masyarakat setempat.

h. Mengikuti sosialisasi atau penyuluhan mengenai pengelolaan sampah RT. Pada kegiatan ini terdapat 7 orang responden yang pernah melakukan kegiatan ini, hal ini menjadikan sosialisasi atau penyuluhan tentang pengelolaan sampah yang baik dilakukan oleh pemerintah atau badan terkait tidak mengena kepada seluruh masyarakat tentang pengetahuan mengenai bagaimana mengelola sampah.

\section{Peran Pemerintah dan Tokoh Masyarakat}

Peran pemerintah dan tokoh masyarakat dalam pengelolaan sampah rumah tangga di Desa Karang Intan dapat dijelaskan bahwa pada dasarnya setiap suatu kegiatan pemerintah yang melibatkan masyarakat akan selalu dikoordinasikan anatar pemerintah dengan tokoh masyarakat. Hal ini dilakukan dengan tujuan agar suatu kegiatan memberdayakan bagi masyarakat tersebut dapat terlaksana dengan baik.

Pengelolaan sampah di Desa Karang Intan, sudah dilakukan sosialisasi maupun pelatihan sebelumnya, namun hanya sebagian masyarakatnya yang menerima atau bahkan yang mengetahui diadakannya suatu kegiatan sosialisasi pengelolaan sampah rumah tangga, dan bahkan dapat dikatakan banyak dari warga masyarakatnya lebih banyak yang tidak mengetahui adanya sosialisasi dan pelatihan mengenai pengelolaan sampah, yaitu 62 responden atau $72,9 \%$. Sedangkan yang mengikuti sosialisasi dan pealtihan sebanyak 23 responden atau $27,1 \%$.

Jika dilihat dari respon para masyarakat yang sebagian besarnya mengatakan bahwa tidak ada sosialisasi maupun pelatihan dalam pengelolaan sampah di Desa Karang Intan, maka dapat dikatakan sosialisasi dan pelatihannya pun tidak di adakan secara rutin. Hal itu bisa diketahui dari jawaban responden bahwa hanya ada 6 responden atau 7,1 \% yang menjawab secara rutin mengikuti sosialisasi dan pelatihan. Sedangkan sebagian besar responden yaitu 79 responden atau 92,9\% mengatakan bahwa tidak secara rutin bisa mengikuti sosialisasi dan pelatihan tersebut. 
Respon masyarakat terhadap kegiatan sosialisasi dan pelatihan yang diberikan pemerintah untuk memberdayakan masyarakatnya kurang mendapat respon positif dari warga masyarakat secara umum, tetapi para tokoh masyarakat pada Desa Karang Intan cukup memberikan respon positif. Respon tokoh masyarakat yang demikian dimaksudkan untuk memberikan contoh dan mengajak atau menghimbau warganya dalam pengelolaan sampah, karena mereka merupakan tokoh yang cukup berpengaruh di Desa Karang Intan bagi kehidupan masyarakatnya. Dengan demikian diharapkan masyarakat dapat mengikuti kegiatan positif yang dilakukan para tokoh masyarakatnya.

Dengan ketimpangan yang terjadi dari respon masyarakat dan tokoh masyarakat di Desa Karang Intan, sulit untuk melihat apakah peran tokoh masyarakat tersebut berpengaruh mengenai perubahan perilaku yang di tunjukkan para warganya dalam mengelola sampah.

Dalam hal para tokoh masyarakat ini memberikan himbauan dan mengajak para warganya untuk melakukan diskusi mengenai sampah agar mengetahui bagaimana pegelolaan sampah, sebagian besar masyarakat yaitu 51 responden atau $60 \%$ mengatakan bahwa warga masyarakat dihimbau dan diajak untuk musyawarah dalam mengelola sampah rumah tangga. Sedangakan sejumlah 34 responden atau $40 \%$ mengatakan tidak diajak musyawarah.

Sebagian warga mengatakan bahwa tidak ada musyawarah antara warga masyarakat dengan tokoh masyarakat, tetapi dapat dilihat dari besarnya respon masyarakat bahwa peran tokoh masyarakat Desa Karang Intan dalam pengelolaan sampah rumah tangga cukup besar.

Peran lain dari tokoh masyarakat yang amat penting selain merupakan panutan dari warganya yaitu dengan memberikan ketegasan atau menegur yang baik bagi para warganya yang melanggar dengan membuang sampah sembarangan. Menurut warga masyarakat Desa Karang Intan, tokoh masyarakat sering menegur warganya apabila membuang sampah sembarangan. Hal ini sebagaimana yang disampaikan masyarakat bahwa 64 responden atau $75 \%$ masyarakat mengatakan tokoh masyarakat akan menegur bila warganya membuang sampah sembarangan, sedangkan 21 responden atau $25 \%$ masyarakat jarang mendapat teguran bila membuang sampah sembarangan. Apabila dilihat dari presentasi dari peran tokoh masyarakat terlihat bahwa mereka sangat peduli terhadap kebersihan lingkungan dalam hal ini mengenai pengelolaan sampah rumah tangga. Sebenarnya, dalam kegiatan pengelolaan sampah ini tidak hanya menjadi tanggungjawab para tokoh masyarakat tetapi para masyarakat itu sendiri yang harus menyadari bahwa menjaga kebersihan lingkungan dari sampah rumah tangga itu sangat penting agar lingkngannya menjadi baik bersih, dan indah.

Warga Desa Karang Intan saling mengingatkan untuk selalu mengelola sampah rumah tangganya dengan baik dan benar, sehingga yang diharapkan tidak hanya peran paraa tokohnya saja yang merupakan panutan, tetapi keikut sertaan masyarakat yang berperan sebagai pegelola sampah.

Peran pemerintah dan para tokoh masyarakat sangat diperlukan untuk menunjang keberlangsungan kegiatan pengelolaan sampah di Desa krang Intan, tetapi pada faktanya peran pemerintah kurang dalam kegiatan pengelolaan sampah baik itu sosialisasi maupun pelatihan, namun dilain pihak peran tokoh masyarakat cukup baik dalam menghimbau masyarakatnya dalam mengelola sampah, sehingga yang diharapkan tidak hanya peran paraa tokohnya saja yang merrupakan panutan didesa karang intan tetapi keikut sertaan masyarakatnya yang berperan sebagai pegelola sampah.

\section{Sarana dan Prasarana dalam Pengelolaan Sampah}

Keberhasilan pengelolaan sampah juga dipengaruhi oleh fasilitas dalam pengelolaan sampah berupa sarana dan prasarana yang tersedia. Hal ini dimungkinkan karena sarana maupun prasarana pengelolaan akan mempengaruhi secara langsung keberhasilan, dengan sarana dan prasarana yang cukup tersediua tentunya akan mempercepat keberhasilan pengelolaan sampah.

Dari hasil penelitian yang kami lakukan di Desa Karang Intan diperoleh data bahwa 
sarana pengelolaan sampah rumah tangga yang tersedia adalah berupa tong sampah.

Tong sampah merupakan salah satu sarana dan prasarana penunjang serta sebagai alat dalam pengelolaan sampah. Tong sampah yang terdapat di Desa Karang Intan sebagai sarana pembuangan sampah, juga sebagai sarana dalam pengelolaan sampah rumah tangga masyarakat Desa Karang Intan. Desa Karang Intan terdapat tong sampah pemisah antara anorganik dan organik, tetapi tong sampah tersebut dalam pengadaannya masih kurang untuk alat tempat pembuangan sampah, karena belum setiap rumah memiliki. Dari tong sampah yang tersedia dalam rumah tangga, ada sebagian masyarakat yang memiliki tong sampah pemisah antara sampah anorganik dan organik. Sedangkan kebanyakan masyarakat yaitu $68 \%$ hanya memiliki satu tong sampah biasa yang terdapat di depan rumah warga desa karang intan, bukan tong sampah pemisah antara organik dan anorganik.

Dengan adanya pengelolaan sampah rumah tangga sudah otomatis bahwa sampah tersebut harus dipisah antara organik dan anorganik, sehingga pengadaan alat berupa tong sampah sebagai penunjang pembuangan sampah pada tempatnya harus sudah mencukupi karena sesuai dengan kebutuhan masyarakatnya, tetapi pada kenyataanya pengadaan tong sampah pada desa karang intan saat ini masih sangat kurang keberadaannya. Keberadaanya tersebut pun dapat dikatakan mewakili dari beberapa rumah, artinya pada setiap rumah tidak memiliki tong sampah terpisah antara tong sampah organik dan tong sampah anorganik.

Sarana pengangkutan sampah juga belum dilaksanakan dengan baik, karena kegiatan pengangkutan sampah belum secara rutin dilakukan sehingga sering menumpuk. Seharusnya pengangkutan sampah Desa Karang Intan dilakukan secara rutin agar tidak terjadinya penumpukan sampah yang terdapat di tong sampah pada setiap RT. Pengangkutan sampah di Desa Karang Intan dilakukan setiap 1 minggu sekali menggunakan motor tosa, motor tosa disediakan oleh pemerintah setiap kampung 1 tosa agar memudahkan pengangkutan sampah secara rutin.

123 | Jumarianta | Pengelolaan Sampah .....
Sampah yang di angkut menggunakan pengangkutan di bawa ketempat pembuangan terpadu untuk dikelola, pembuangan terpadu tersebut terdapat di desa Lihung yang berbatasan langsung dengan desa karang intan. Ada pula sebagaian kecil masyarakatnya yang tidak mengetahui bahwa sampah di angkut ke pembuangan sampah terpadu. Tetapi secara garis besar masyarakat Karang Intan lebih banyak mengetahui bahwa sampah tersebut diangkut secara rutin ketempat pembuangan sampah terpadu.

\section{Partisipasi Masyarakat dalam Pengelolaan Sampah}

Partisipasi masyarakat dalam pengelolaan sampah merupakan keterlibatan masyarakat dalam proses-proses pengelolaan sampah mulai dari diri sendiri, yang dapat dilakukan secara langsung berarti masyarakat aktif menyumbangkan tenaga dalam proses pengelolaan sampah, seperti pemakaian bahan yang masih dapat digunakan untuk mengurangi sampah, memilah sampah, mengangkut ke tempat pembuangan sementara memanfaatkan sampah kembali, dan mengikuti kegiatan kebersihan lingkungan.

Sampah organik termasuk sampah yang mudah diuraikan oleh bakteri pengurai dengan proses alami dan berlangsung dengan cepat. Sedangkan Sampah Anorganik adalah sampah yang tidak dapat diperbaharui lagi serta sampah yang berasal dari proses industri.

Pada desa Karang Intan yang terdiri dari 3 RT mayoritas masyarakat dalam pengelolaan sampah rumah tangga masih sedikit kurang mengerti dalam pemisahan sampah organik dan anorganik. Karena faktor pendidikan masyarakatnya masih rendah dan tidak adanya suatu pengarahan tertentu dalam pemisahan sampah organik maupun anorganik. Namun di sisi lain masyarakatnya juga masih ada sebagian yang mengerti tentang pemisahan sampah organik dan anorganik. Menurut fakta yang kami lihat dilapangan masyarakat Desa Karang Intan dalam pengelolaan sampah rumah tangga baik sampah organik maupun anorganik hanya dijadikan dalam satu wadah plastik dan tidak adanya pembedaan bak sampah antara sampah organik dan anorganik jadi masyarakatmya 
tidak memiliki keinginan ingin tahu tentang pembedaan sampah organik dan anorganik jdi sampah nya di buang dalam bank sampah sementara hanya di jadikan satu saja.

Dari pertumbuhan penduduk yang semakin meningkat maka semakin bertambah pula nilai konsumtif masyarakatnya sehingga mengakibatkan meningkatnya pemakaian kantung plastik yang digunakan untuk berbelanja yang pada akhirnya akan menambah volume sampah rumah tangga.

Kurangnya fasilitas bank sampah di desa Karang Intan mengakibatkan sebagian masyarakatnya sulit untuk membuang sampah ke tempat penampungan sampah sementara. Karena bank sampah hanya ada di pinggiran jalan umum. Sedangkan masyarakat Desa Karang Intan cenderung letak perumahannya berlapis, jadi bagi yang rumahnya berada di belakang cenderung tidak membuang sampah ketempat pembuangan sampah sementara karena jaraknya lumayan jauh dan mereka memilih untuk dibakar. Dari data yang kami peroleh dilapangan, petugas pengangkutan sampah dari bank sampah sementara ke tempat pembuangan sampah akhir hanya mengambil dari bank sampah sementara.

Minimnya pengetahuan masyarakat desa Karang Intan tentang pemanfaatan barang bekas yang masih bisa digunakan untuk dijadikan barang kerajinan, kerajinan tangan dari barang bekas merupakan salah satu cara untuk mengolah sampah yang ada dilingkungan sekitar supaya volume sampah yang dihasilkan oleh rumah tangga setiap harinya berkurang.

Bentuk lain partisipasi masyarakat dalam pengelolaan sampah adalah kegiatan bersih desa seperti kerja bakti atau gotong royong. Masyarakat Desa Karang Intan sering melakukan kerja bakti atau gotong royong dilingkungan desanya, kegiatan ini dirasa sangat besar manfaatnya bagi masyarakat karena akan meningkatkan nilai solidaritas, kekeluargaan, kebersamaan juga menciptakan lingkungan yang bersih. Kekompakan dan kekeluargaan warga masyarakat Desa Karang Intan sangat erat karena saling memiliki kesadaran akan pentingnya gotong royong untuk menjaga lingkungan sekitarnya.

\section{KESIMPULAN}

1. Karakteristik masyarakat, secara umum karakteristik masyarakat Desa Karang Intan dari segi pendidikan rata-rata lulusan SD yaitu sebanyak $36,4 \%$, sedangkan lulusan SLTP sebanyak 29\%, lulusan SLTA 23,5\% sedangkan sarjana sebanyak 3,5\%. Dari segi pendidikan bisa disimpulkan bahwa masyarakat Desa Karang Intan masih rendah. Sementara pekerjaan pokok penduduk di dominasi petani, swasta, dan pedagang.

2. Pengalaman dalam pengelolaan sampah dilingkungan, kegiatan-kegiatan yang ada dalam pengelolaan sampah itu sebagian besar pernah dialami atau dilakukan oleh responden, kegiatan yang mendominasi dari semua kegiatan-kegiatan yang adea adalah memindahkan sampah-sampah ke TPS, dan kerja bakti membersihkan lingkungan artinya kegiatan yang mendominasi tersebut menunjukan bahwa masyarakat mempunyai kesadaran baik itu secara langsung atau tidak langsung untuk menjaga lingkungan agar tetap asri.

3. Peran pemerintah dan tokoh masyarakat, 64 $\%$ dari responden masyarakat mengakui bahwa adanya peran yang sangat penting dari tokoh masyakat setempat, sedangkan 36 $\%$ masyarakat mengungkapkan tidak adanya peran dari pemerintah baik itu dalam hal pemberian sosialisai/ pelatihan bagaimana cara mengelola sampah yang baik.

4. Sarana prasarana pengelolaan sampah, 58\% dari responden menyatakan bahwa sarana prasarana pengelolaan sampah Didesa Karang Intan masih kurang, dah sisanya $32 \%$ beranggapan bahwa sarana prasarana sudah cukup hal ini dikarenakan masyarakat yang menjawab tersebut, berada dimuka muka jalan yang terdapat bak - bak sampah. $10 \%$ dari responden tidak ada memberikan jawaban.

5. Persepsi terhadap pengelolaan sampah, $78 \%$ masyarakat mengungkapkan kesetujuanya terhadap cara - cara yang baik dalam pengelolaan sampah agar baik, dan 14\% yang cukup memberikan dukungannya 
terhadap pengelaan sampah, dan 6\% memberikan tanggapan yang kurang setuju dengan alasan pengeloaan itu sulit untuk dilakukan.

6. Partisipasi terhadap pengelolaan sampah seccara langsung, 54\% responden tidak melaksanakan kegiatan - kegiatan secara langsung untuk menelola lingkungan, dan $16 \%$ jaran melakukan, dan sebagian $7 \%$ responden cukup sering dan $16 \%$ sering melakukan kegiatan pengelolaan sampah, dan $7 \%$ tidak ada responden.

\section{REFERENSI}

Abdurachman M. 1988. Geografi Perilaku: Suatu Pengantar Studi Tentang Persepsi Lingkungan. Jakarta (ID): P2LPTK.

Budiman RA, Saam Z, Thamrin. 2013. Partisipasi dan persepsi masyarakat dalam upaya menjaga mengelola lingkungan hidup dan mempertahankan predikat kota bersih. Jurnal Ilmu Lingkungan [Internet]. [diunduh 2017 Oktober 9].

Candra I. 2012. Partisipasi masyarakat dalam pengelolaan sampah rumah tangga (Studi kasus di Kelurahan Siantan Tengah Kecamatan Pontianak Utara). Sociodev-Jurnal Ilmu Sosiatri [internet]. [diunduh 2013 oktober 9]; 1(1):1-21. Tersedia pada: http:// jurnalmahasiswa.

fisip.untan.ac.id/index.php/jurnalsosiat ri/article/view/140.

[DPU] Dinas Pekerjaan Umum. 2007. Pedoman Umum 3R Berbasis Masyarakat di Kawasan Pemukiman. Jakarta (ID): Direktorat Pengembangan Penyehatan Lingkungan Pemukiman.

Harihanto. 2001. Persepsi, Sikap, dan Perilaku Masyarakat Terhadap Air Sungai
(Kasus: Di DAS Kaligarang, Jawa Tengah) [disertasi]. Bogor (ID): Institut Pertanian Bogor.

Koentjaraningrat. 1991. Metode-Metode Penelitian Masyarakat. Jakarta (ID): Gramedia.

Muchtar T. 1998. Hubungan karakteristik elit formal dan elit informal desa dengan persepsi dan tingkat partisipasi mereka dalam program P3DT di Kabupaten Sukabumi [tesis]. Bogor (ID): Institut Pertanian Bogor.

Peraturan Pemerintah Republik Indonesia Nomor 81 Tahun 2012 Pengelolaan Sampah Rumah Tangga dan Sampah Sejenis Rumah Tangga. 15 Oktober 2012. Tambahan Lembaran Negara Republik Indoenesia Tahun 2012 Nomor 5347. Jakarta.

Riani. 2014. Bank Sampah di Kota Tangerang Belum Maksimal [Internet]. [diunduh 2017 Oktober 13].

Rianse U, Abdi. 2009. Metodologi Penelitian Sosial dan Ekonomi. Jakarta (ID): Alfabeta.

Sarwono SW. 1995. Psikologi Lingkungan. Jakarta (ID): Grasindo \& Program Pascasarjana Prodi Psikologi UI.

Sumardjo. 2009. Teknologi partisipatif pengembangan masyarakat. Modul Kuliah. Departemen Sains Komunikasi dan Pengembangan Masyarakat. Fakultas Ekologi Manusia. Institut Pertanian Bogor.

Undang-Undang Republik Indonesia Nomor 18 Tahun 2008 Pengelolaan Sampah. 7 Mei 2008. Lembaran Negara Republik Indonesia Tahun 2008 Nomor 69. Jakarta.

Yolarita E. 2011. Pengelolaan sampah dengan prinsip 3R di Kota Solok [tesis]. Bandung (ID): Universitas Padjajaran. [Internet]. [diunduh 2017 Oktober 2]. 